\title{
Earthworms stimulate pasture production in sheep and beef systems: their economic value
}

\author{
N.L. SCHON ${ }^{1}$, R.A. GRAY ${ }^{2}$ and A.D. MACKAY ${ }^{2}$ \\ ${ }^{1}$ AgResearch, Lincoln Research Centre, Private Bag 4749, Christchurch 8140, New Zealand \\ ${ }^{2}$ AgResearch, Grasslands Research Centre, Private Bag 11008, Palmerston North 4442, New Zealand
}

Nicole.schon@agresearch.co.nz

\begin{abstract}
Earthworms have long been recognised to promote plant growth but their contribution to pasture production in managed pastures may be undervalued. At three field sites pasture production was measured in an area where surface active communities were found compared to a more diverse area where the additional deep burrowing earthworm Aporrectodea longa had been introduced. Caution is needed when interpreting the results, as all data are from paired areas and not replicates. The influence of earthworms on pasture production was positively correlated with the difference in abundance of the topsoil species Aporrectodea caliginosa, with this species being more abundant in the presence of A. longa at two sites. Overall, the value of diverse earthworm communities to pasture production was estimated to be $\$ 365-\$ 440 /$ ha annually. In managed pasture systems there is need to recognise the value of maintaining and enhancing earthworm populations.
\end{abstract}

Keywords: pasture production, earthworm functional diversity

\section{Introduction}

The contribution of earthworms to the maintenance of soil quality is widely documented, including their contribution to soil aggregate building, pore structure creation, nutrient cycling, and decomposition of plant material (Edwards \& Bohlen 1996). All of these processes are essential for sustaining pasture production. Early research in New Zealand found that the introduction of exotic earthworms could increase pasture production by more than 20\% (Stockdill 1982). In a recent meta-analysis of global studies on the benefits of earthworm introductions, van Groenigen et al. (2014) found increased grass production ranged from $20-30 \%$.

Despite the numerous reports of earthworms increasing pasture growth, few studies have quantified pasture production gains and its economic value. Stockdill (1982) calculated that the introduction of an exotic surface active earthworm species (Aporrectodea caliginosa) increased pasture growth to the degree that enables an extra 2.5 stock units/ha to be carried. At current market value this is worth about \$290/ha annually in revenue (www.beeflambnz.com). There are no data on the economic benefits of extending the exotic earthworm introductions beyond the surface active species to include deep burrowing species like Aporrectodea longa, which are often absent from New Zealand pasture soils (Schon et al. 2011).

This study reports on pasture production at three locations where deep burrowing species had been introduced to address the lack of earthworm species diversity. Caution is needed when interpreting the results, as all data were from paired areas and not replicates. As a consequence, differences in pasture growth between areas containing both the surface and deep burrowing earthworm species and adjacent areas where only surface active species were present, cannot be attributed to the presence of the deep burrowing earthworms alone. However, it can be determined for areas where the deep burrowing species are present, if they produce more or less pasture than areas where they have yet to migrate and colonise.

\section{Methods}

The three sites selected for measuring the impact of earthworm diversity on pasture production were located on sheep and beef properties and included:

- Mounganui, in the central Southern North Island near Taihape

- Rangitoto, on the East Coast near Porangahau

- Ballantrae, an AgResearch farm on the foothills of the Ruahine ranges, near Woodville.

Rangitoto was classified as early, Ballantrae as mid and Mounganui late lambing country. The soil was free draining at Mounganui (Allophanic), moderately well drained at Ballantrae (Brown) and poorly drained at Rangitoto (Pallic soil).

At each of the three sites the deep burrowing earthworm A. longa had been introduced more than a decade previously and had since become well established. Areas were identified by collecting soil turves and hand-sorting earthworms. 'Diverse' areas had established populations of $A$. longa and adjacent areas where $A$. longa had yet to migrate and establish, were referred to as 'surface active'. In 2014, paired areas if possible within the same paddock otherwise in a nearby paddock, were selected to be as similar as possible in terms of slope and aspect. On each farm the paired areas were replicated three times and all received 
lime at a rate of 2.5 tonne/ha. Earthworm abundance in both areas had been previously assessed (Table 1). There were three fertiliser treatments: control, nitrogen (60 kg N/ha as urea, in two applications) and phosphorus treatment (20 kg P/ha as superphosphate) that were randomly applied in 2014 to $2 \times 2 \mathrm{~m}$ plots on both the surface active and diverse areas of each pair.

From October 2015 to October 2016 pasture production was assessed every 4-8 weeks, depending on pasture growth rates, using exclusion cages $\left(0.5 \mathrm{~m}^{2}\right)$. Pasture was trimmed to a $2 \mathrm{~cm}$ stubble, weighed, dried at $60^{\circ} \mathrm{C}$ and weighed again. A simple analysis of the effect on farm productivity was conducted using Farmax (Bryant et al. 2010). The base farm was modelled using the 2013-2014 Beef + Lamb New Zealand farm survey for an average Class 3 North Island Hard Hill Country in the Taranaki/Rangitikei/Manawatu region. Class 3 farms carry mainly breeding stock (six to nine livestock units/ha) with some stock sold in prime condition, but most sold as stores. In this analysis no attempt was made to alter or optimise the farm management, pasture production was altered to mimic the two treatments and stock numbers were increased until pasture utilisation was feasible. The changes in net animal production between the diverse and surface active treatments were recorded.

Earthworm species abundance were compared between the diverse and surface active areas within each site using a generalised linear model and assuming negative binomial distributions with a log link function (SAS 9.3) (Schon et al. 2014). Pasture production on individual dates were analysed using ANOVA (SAS 9.3) and cumulative pasture production was assessed using two-sample $t$ tests, assuming unequal variances. This study does not allow for removal of factors from the analysis that could have contributed to the differences in pasture growth, other than differences in the earthworm community. Only two paired areas at Rangitoto were included in the analysis. Regression analysis was conducted to investigate the relationship of pasture production with total earthworm abundance, A. caliginosa abundance and $A$. longa abundance for both areas (Minitab 16).

\section{Results}

At Mounganui and Ballantrae total earthworm abundance was greater in the diverse than the surface active area with more $A$. caliginosa as well as $A$. longa (Table 1). At Rangitoto earthworm abundance was similar in the two areas, with the diverse area containing more $A$. longa but less A. caliginosa than the surface active area.

Pasture production was higher in areas containing the diverse earthworm community compared to the areas where only the surface active were present (Figure 1). The increases in pasture production ranged from $5-45 \%$ across all sites where the diverse earthworm community was present. The additional earthworm diversity had the greatest impact on pasture growth from autumn through to early spring, the period when earthworms are most active. The value of the extra pasture grown annually on the areas containing the more diverse earthworm community was calculated as (potentially) equivalent to $\$ 440$ at Mounganui, $\$ 365$ at Rangitoto and $\$ 410 /$ ha at Ballantrae, or a $7-27 \%$ increase in gross margin/ha (Table 2).

There was a strong positive relationship between pasture production and A. caliginosa abundance explaining $47 \%$ of the variation in pasture production $(\mathrm{P}=0.041)$. This relationship was weaker when all

Table 1 Mean earthworm abundance $\left(\right.$ number $\left./ \mathrm{m}^{2}\right)$ at the three sites in both the surface active and diverse transects (Schon et al. 2014; R.A. Gray pers. comm. 2014). Data in bold type indicate a significant difference at $a=0.05$ between the surface active and diverse transect at a given site for each species.

\begin{tabular}{|c|c|c|c|c|c|c|}
\hline \multirow[b]{3}{*}{ Earthworm species } & \multicolumn{6}{|c|}{ Number of earthworms $/ \mathrm{m}^{2}$} \\
\hline & \multicolumn{2}{|c|}{ Mounganui } & \multicolumn{2}{|c|}{ Rangitoto* } & \multicolumn{2}{|c|}{ Ballantrae } \\
\hline & Diverse & Surface & Diverse & Surface & Diverse & Surface \\
\hline Aporrectodea longa (Ude, 1885) & 327 & 0 & 371 & 0 & 208 & 0 \\
\hline Aporrectodea caliginosa (Savigny, 1826) & 274 & 44 & 883 & 1484 & 817 & 336 \\
\hline Aporrectodea rosea (Savigny, 1826) & 0 & 0 & 170 & 80 & 667 & 693 \\
\hline Aporrectodea trapezoides (Dugès, 1828) & 0 & 0 & 88 & 239 & 0 & 0 \\
\hline Octolasion cyaneum (Savigny, 1826) & 9 & 0 & 0 & 0 & 9 & 31 \\
\hline Lumbricus rubellus (Hoffmeister, 1843) & 367 & 233 & 0 & 0 & 26 & 26 \\
\hline New Zealand native $s p p$ & 27 & 18 & 0 & 0 & 4 & 102 \\
\hline Total earthworms & 1004 & 265 & 1513 & 1802 & 1731 & 1188 \\
\hline
\end{tabular}

* L. rubellus has been previously recorded at Rangitoto (R.A. Gray pers. comm. 2014). 
earthworm species were included in the measure of abundance, when only $34 \%$ of the variation was explained $(\mathrm{P}=0.097)$. Pasture production had a negative relationship with $A$. longa abundance explaining $41 \%$ of the variation $(\mathrm{P}=0.061)$.

The pasture response to superphosphate addition was higher on the diverse areas at both Mounganui and Ballantrae (Figure 1).
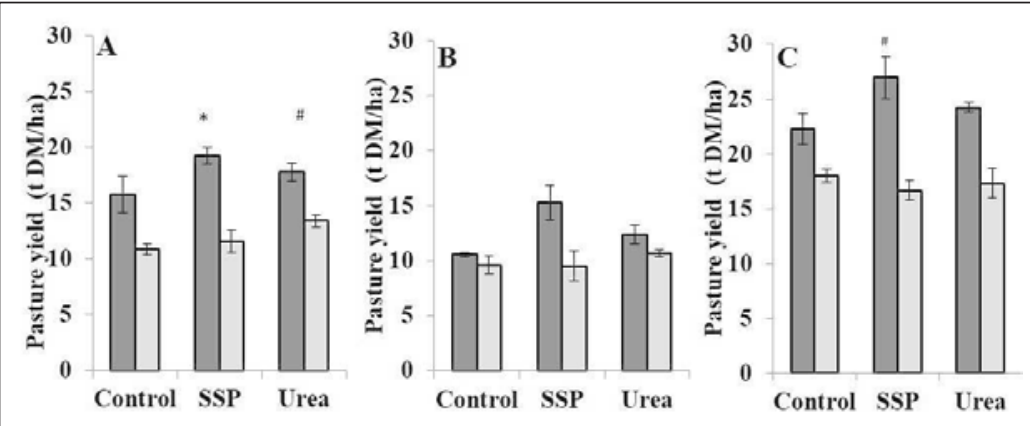

Figure 1 Annual pasture yield response to fertiliser (Control = no fertiliser treatment; SSP = superphosphate treatment; Urea = nitrogen treatment) on the diverse $(\square)$ and surface active areas ( $\square$ ) at A) Mounganui, B) Rangitoto and C) Ballantrae. ${ }^{*}=\mathrm{P}<0.05,{ }^{*}=\mathrm{P}<0.1$. Error bars are SEM.

Pasture on the areas only containing the surface active earthworm species did not respond to $\mathrm{P}$ addition. A pasture response to $\mathrm{N}$ was only measured on the diverse area at Mounganui, the least developed of the three locations.

\section{Discussion}

This study indicates that a diverse earthworm community may be beneficial to pasture growth, there being a large difference in annual pasture production between the two areas (5-45\% more on the diverse pasture areas). Although increased production cannot be directly attributed to the addition of a third earthworm functional group, other studies have also reported increased pasture production after the introduction of both A. caliginosa (Stockdill 1982) and A. longa (Syers \& Springett 1984). Further, a comparison of pasture production at Ballantrae at the same locations that were sampled in this study before A. longa introduction (1982-1987) (A.D. Mackay pers. comm. 2016) suggests that differences in pasture production were not always present between the sites. Historically, pasture production in the surface active area was similar to the current measurements (16 930 versus $17600 \mathrm{~kg} \mathrm{DM} / \mathrm{ha}$, respectively). Before the introduction of $A$. longa in the diverse areas pasture production was similar to the surface active area, but this changed after their introduction (15 525 versus $25000 \mathrm{~kg} \mathrm{DM} / \mathrm{ha}$, respectively). The diverse area at Ballantrae was not naturally more fertile, with soil phosphorus fertility being lower in 2003 in the area where $A$. longa was subsequently introduced compared to the surface active area (Olsen P of 29 versus $43 \mu \mathrm{g} /$ $\mathrm{ml}$, respectively). Although earthworms are stimulated by increased pasture productivity (Curry et al. 2008), the changes at Ballantrae suggest that earthworms may also be enhancing productivity.

In the presence of $A$. longa, $A$. caliginosa became more abundant at two of the three sites. At Mounganui where the greatest differences in earthworm abundance were observed (Table 1), there were also the largest differences in pasture production (Figure 1). There was a strong correlation between earthworm abundance and dry matter production across the three sites for $A$. caliginosa. In contrast, there was a negative correlation with $A$. longa, with the range of their abundance between treatments being much smaller compared to $A$. caliginosa.

Differences in pasture production between the earthworm treatments were still apparent after fertiliser application, especially after the addition of superphosphate. The smaller influence of earthworms after nitrogen application may reflect the smaller

Table 2 Additional production ( $\mathrm{kg} \mathrm{DM} / \mathrm{ha}$ ), as modelled in Farmax in the diverse earthworm transect and its economic value (as a percentage increase in gross margin/ha), in comparison to the surface active transect at the three sites.

\begin{tabular}{|c|c|c|c|c|c|c|}
\hline \multirow[b]{2}{*}{ Farm system } & \multicolumn{2}{|c|}{ Mounganui } & \multicolumn{2}{|c|}{ Rangitoto } & \multicolumn{2}{|c|}{ Ballantrae } \\
\hline & $\begin{array}{l}\text { Increase } \\
\mathrm{kg} \mathrm{DM} / \mathrm{ha}\end{array}$ & $\begin{array}{c}\text { Increase } \\
\%\end{array}$ & $\begin{array}{l}\text { Increase } \\
\mathrm{kg} \mathrm{DM} / \mathrm{ha}\end{array}$ & $\begin{array}{c}\text { Increase } \\
\%\end{array}$ & $\begin{array}{l}\text { Increase } \\
\mathrm{kg} \mathrm{DM} / \mathrm{ha}\end{array}$ & $\begin{array}{c}\text { Increase } \\
\%\end{array}$ \\
\hline Sheep & 85.6 & 27 & 71.8 & 7 & 80.1 & 19 \\
\hline Wool & 40.1 & 27 & 33.5 & 6 & 37.7 & 20 \\
\hline Beef & 39.3 & 26 & 33.1 & 6 & 36.6 & 18 \\
\hline Total production & 165.0 & 27 & 138.4 & 6 & 154.4 & 19 \\
\hline
\end{tabular}


pasture response to nitrogen fertiliser (Gillingham et al. 1998). Further, the impact of earthworms on pasture growth was reduced when more nitrogen was available within the soil and more nitrogen fertiliser was applied (van Groenigen et al. 2014). This study suggests that earthworms were able to increase the value received from fertilisers by stimulating pasture production, especially in the case of superphosphate application.

In all treatments, except the surface active treatment at Mounganui, total earthworm abundance was greater than $1000 / \mathrm{m}^{2}$. Abundances of greater than $1000 / \mathrm{m}^{2}$ are high for pasture internationally (Curry 1994) but fall within reported field values for New Zealand, which can range from zero to over $1000 / \mathrm{m}^{2}$ (Schon et al. 2011). van Groenigen et al. (2014) observed a greater pasture production response as earthworm abundance increased above $400 / \mathrm{m}^{2}$. Hence, the variability in earthworm abundance across New Zealand pastures $(0$ to $>1000 / \mathrm{m}^{2}$ ) affects pasture production. Minimising physical constraints and providing sufficient food as organic matter encourages earthworm populations to stimulate extra forage production that could amount to over $\$ 365 /$ ha annually. More research is required into options for increasing the earthworm diversity and activity in managed pasture systems to maximise the soils natural capacity for pasture production.

\section{ACKNOWLEDGEMENTS}

We thank Beef + Lamb New Zealand for funding this project, C. van Koten (AgResearch) for statistical analysis and B. Devantier (AgResearch) for Farmax analysis.

\section{REFERENCES}

Bryant, J.R.; Ogle, G.; Marshall, P.R.; Glassey, C.B.; Lancaster J.A.S.; Garcíad, S.C.; Holmes, C.W. 2010.
Description and evaluation of the farmax dairy pro decision support model. New Zealand Journal of Agricultural Research 53: 23-28.

Curry, J.P. 1994. Grassland Invertebrates: Ecology, influence on soil fertility, and effects on plant growth. Chapman \& Hall, New York. 437 pp.

Curry, J.P.; Doherty, P.; Purvis, G.; Schmidt, O. 2008. Relationships between earthworm populations and management intensity in cattle-grazed pastures in Ireland. Applied Soil Ecology 39: 58-64.

Edwards, C.A.; Bohlen, P.J. 1996. Biology and Ecology of Earthworms. Chapman \& Hall, London, UK. 426 pp.

Gillingham, A.G.; Gray, M.H.; Smith, D.R. 1998. Pasture responses to phosphorus and nitrogen fertilisers on dry hill country. Proceedings of the New Zealand Grassland Association 60: 135-140.

Schon, N.L.; Mackay, A.D.; Gray, R.A.; Dodd, M.B. 2014. The action of an anecic earthworm (Aporrectodea longa) on vertical soil carbon distribution in New Zealand pastures several decades after their introduction. European Journal of Soil Biology 62: 101-104.

Schon, N.L.; Mackay, A.D.; Minor, M.A. 2011. Earthworms in New Zealand sheep- and dairy-grazed pastures with focus on anecic Aporrectodea longa. Pedobiologia 54: S131-137.

Stockdill, S.M.J. 1982. Effects of introduced earthworms on the productivity of New Zealand pastures. Pedobiologia 24: 281-299.

Syers, J.K.; Springett, J.A. 1984. Earthworms and soil fertility. Plant and Soil 76: 93-104.

van Groenigen, J.W.; Lubbers, I.M.; Vos, H.M.J.; Brown, G.G.; De Deyn, G.B.; van Groenigen, K.J. 2014. Earthworms increase plant production: a metaanalysis. Scientific Reports 4: 1-7. 